
${ }^{5}$ White NJ, Winearls CG, Smith R. Cardiovascular abnormalities in osteogenesis imperfecta
Am Hean $\mathcal{f}$ 1983;106:1416-20.

${ }^{6}$ Paterson CR, McAllion S, Miller R. Heterogeneity of osteogenesis imperfecta type I. $\mathcal{J}$ Med Genet 1983;20:203-5.

Paterson CR, McAllion S, Miller R. Osteogenesis imperfecta with dominant inheritance and normal sclerae. F Bone foint Surg [Br] 1983;65:35-9.

pranger J, Cremin B, Beighton P. Osteogenesis imperfecta congenita. Features and prognosis of a heterogeneous condition. Pediatr Radiol 1982;12:21-7.

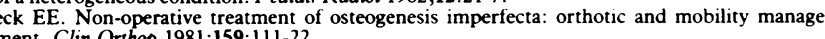
ment. Clin Orthop 1981;159:111-22.

Pozo JL, Crockard HA, Ransford AO. Basilar impression in osteogenesis imperfecta. A report of three cases in one family. $\mathcal{F}$ Bone foint Surg $[B r]$ 1984;66:233-8.

Lubs HA, Travers H. Genetic counselling in osteogenesis imperfecta. Clin Orthop 1981;159:

Shapiro JE, Phillips JA, Byers PH, et al. Prenatal diagnosis of perinatal osteogenesis imperfecta (OI type II). F Pediatr 1982;100:127-33.

Kelly TE, Hall JG, Horton W, Scott CI. Prenatal diagnosis of genetic osteochondrodysplasias. Am $\mathrm{f}$ Med Genet $1983,16.285-7$.

mith R, Francis MJO. Disorders of collagen biosynthesis. In: O'Riordan JLH, ed. Recent advances in $211-38$.

15 Gay S, Miller EJ. What is collagen, what is not. Ultrastruct Pathol 1983;4:365-77.

${ }_{16}$ Francis MJO, Williams KJ, Sykes BC, Smith R. The relative amounts of the collagen chains al(I) $\alpha^{2}$ and $\alpha \mathrm{l}(\mathrm{III})$ in the skin of 31 patients with osteogenesis imperfecta. Clin Sci 1981;60: $617-23$

Bateman JF, Mascara T, Chan T, Cole WG. Abnormal type I collagen metabolism by cultured fibroblasts in lethal perinatal osteogenesis imperfecta. Biochem $\mathcal{F}$ 1984;217:103-15.

Boehm CD, Antonarakis SE, Phillipps JA, Stetten G, Kazazian HH. Prenatal diagnosis using DNA polymorphisms. $N$ Engl I Med 1983;308: 1054-8.

Chu M-L, Williams CJ, Pepe G, Hirsch JL, Prockop DJ, Ramirez F. Internal deletion in a collagen gene in a perinatal lethal form of osteogenesis imperfecta. Nature 1983;304:78-80.

sipouras P, Myers JC, Ramirez F, Prockop DJ. Restriction fragment length polymorphis associated with the pro $\alpha 2(\mathrm{I})$ gene of human type I procollagen. F Clin Invest 1983;72:1262-7. Sykes BC. Collagen and inherited connective tissue diseases. Nature 1983;305:764

Pope FM, Cheah KSE, Nicholls AC, Price AB, Grosveld FG. Lethal osteogenesis imperfecta ( $1380-1$.

(3) BC, Francis MJO, Smith R. Altere

imperfecta. N Engl f Med 1977;296:1200-3.

Solomon E. Collagen genes. Nature 1982;300:581-2.

\section{Familial hypercholesterolaemia: renewed interest in an old problem}

Familial hypercholesterolaemia is an autosomal dominant disorder which was first described more than 100 years ago. It is distinguished from other causes of hyperlipidaemia by the typical cutaneous manifestations (xanthomas), a particularly high risk of premature cardiovascular disease, and a distribution in families compatible with the mode of inheritance. The xanthomas, nodules filled with cholesterol, are most classically seen in the extensor tendons at the back of the hands and in thickened Achilles tendons. The presence of xanthelasma and premature corneal arcus are suggestive but not diagnostic of the condition. ${ }^{1}$

Untreated, the outlook is poor: half of all men suffering from familial hypercholesterolaemia may expect to die from coronary heart disease by the age of $60 .^{2}$ In the rare homozygous form symptoms of coronary heart disease may occur in childhood.

The condition results from a genetic deficiency of specific cell surface receptors normally responsible for removing cholesterol rich low density lipoprotein, and blood lipid analysis will usually show a substantially raised concentration of total cholesterol as a result of increased levels of low density lipoprotein cholesterol (in adults usually greater than $5 \mathrm{mmol} / \mathrm{l}$ ) with other lipid and lipoprotein concentrations relatively normal. ${ }^{3}$ Familial hypercholesterolaemia may be diagnosed from cord blood at birth. On the basis of the number of known homozygotes, Slack has estimated a frequency of one in 500 in Britain, but in some other countries (for example, South Africans of Dutch origin) rates are believed to be substantially. higher. ${ }^{4}$

In view of the fairly high frequency, the ominous prognosis in untreated sufferers, and the relative ease of diagnosis it is surprising that the condition has not aroused greater interest. This probably results from a failure by clinicians to appreciate how common the condition is and the lack of evidence that treatment improves the outlook. Effective lowering of cholesterol by dietary modification and drug treatment can certainly reduce the size of the xanthomas. Recently the Lipid Research Clinics' much publicised trial of patients treated with cholestyramine (which included some with familial hypercholesterolaemia) has confirmed the circumstantial evidence suggesting that adequate lowering of cholesterol can produce an appreciable reduction in morbidity and mortality from cardiovascular disease. ${ }^{56}$ As a result of the trial cholestyramine is widely regarded as the drug of choice in patients resistant to dietary treatment (most of those with familial hypercholesterolaemia), but probucol, nicotinic acid, and bezafibrate have been used in the few patients not able to tolerate cholestyramine. These drugs have also been used in conjunction with cholestyramine when it alone has not produced adequate lowering of cholesterol. Ileal bypass surgery has been used with some success in a few specialist centres in patients resistant to drug treatment. Management of the rare homozygous form presents special problems reviewed in detail elsewhere. ${ }^{7}$ Against this background patients with familial hypercholesterolaemia have formed a new self help organisation - the Familial Hypercholesterolaemia Association-which aims to make the public and medical profession more aware of the condition, to inform and support those found to have familial hypercholesterolaemia, and to encourage further research into the cause and treatment of the condition. Its address is PO Box 612, London W2 2EE.

\section{J I MANN}

University Lecturer and Honorary Consultant Physician,

University Department of Community Medicine and General Practice,

Radcliffe Infirmary,

Oxford OX2 6HE

Lewis B. Disorders of lipid transport. In: W'eatherall DJ, Ledingham JGG, Warrell DA, eds Oxford textbook of medicine. 1st ed. Oxford: Oxford University Press, 1983:9.58-9.70.

Risk of ischaemic heart disease in familial hyperlipoproteinaemic states. Lancel 1969, ii: $1380-2$

Brown MS, Goldstein JL. Receptor mediated control of cholesterol metabolism. Science 1976;181:150-3.

Goldstein JL, Brown MS. Familial hypercholesterolaemia. In: Stanbury JB, Wyngaarden JB Fredrickson DS, Goldstein JL, Brown MS, eds. Metabolic basis of inherited disease. 5th ed Hightstown NJ: McGraw Hill Book Co, 1983:672-712.

Lipid Research Clinics Programme. The lipid clinics coronary primary prevention trial results. I. Reduction incidence of coronary heart disease. JAMA 1984;251:351-64.

Lipid Research Clinics Programme. The lipid clinics coronary primary prevention trial results. II The relationship of reduction in incidence of coronary heart disease to cholesterol lowering. Thompson GR,

NB. Plasma exchange in the management of homozygous familial hypercholesterolaemia Lanci:1208-10.

\section{Medical education and manpower in the European Economic Community}

Without having anything quite like a common medical policy the European Economic Community has achieved a doctor mountain. What to do with it is a headache for all of those concerned, and that must potentially include Britain. We can scarcely plough doctors back into the ground or sell them cheap to the Russians. Nobody doubts that they could be helpful in the world, given the right opportunities for their use. So could butter and eggs and milk and, some might say, even wine. Cutting down their production will not make doctors go away; their very imperishability, as well as their social and economic value, intensifies the embarrassment of their overproduction.

While we are trying to decide whether Britain is itself training too many doctors (and our problem, if it exists at all, 
is tiny) we naturally worry about the implications of free movement. It seems strange to fear the Greeks when they come bearing the gifts of EEC membership, since we have for so long depended on the medical fruits of the Indian subcontinent to nurture the NHS. Yet times have changed. Although the General Medical Council is now exercising much control and discrimination over which overseas medical qualifications it will recognise it has been robbed of all such authority in respect of the EEC. There is no inspection of continental medical schools, nor qualitative assessment; 5500 hours of instruction over six years, with EEC nationality, carries automatic entitlement to full registration. We know very little about the standard of the "average" medical graduate of Italy or West Germany; what we do know-the performance in the past in the language examination of some doctors from countries now exempted by their new EEC membership-is not too reassuring. And there is not, as yet, much information about the thoroughness with which health authorities are testing linguistic and professional competence before employing EEC doctors. We are left with an uncomfortable sense of lost control with little gained in exchange.

A survey of the EEC countries shows how many wayssome tried, some theoretical-there are of trying to control medical manpower: limiting entry to the medical schools, cutting down undergraduate numbers after the first year, regulating postgraduate training opportunities by specialty and area, restricting the scope of practice by specialist registration, controlling the emigration of doctors, throttling the inflow of foreign doctors, and fixing the retirement age. In addition may be found different attitudes to part time training and different labour markets leading sometimes to partial employment of doctors who cannot find enough work to maintain their competence. Some end up in a state of "intellectual unemployment," practising fringe medicine or doing paramedical work to make a living.

Language difficulties are a barrier to free movement of doctors-and so they should be, unless adequately overcome. On the other hand, the Common Market arrangement has required the levelling up of training and educational requirements. This makes our membership, and that of Ireland, important to medicine in the rest of the EEC. But we set a curious example, for all our great traditions. Much of our postgraduate training is appallingly badly organised, inefficient, and unnecessarily long. It is beset by a complex network of diploma examinations which, inconsistent in their purpose and timing as between specialties and even between colleges in the same specialty, are no basis on which the rest of western Europe could model itself-even if it wished to emulate our apparent love of such tests. We may have to learn how to reconcile our criteria for specialist or consultant status with the claims of EEC doctors who have not passed postgraduate examinations or complied with the rigours of our higher professional training and who may be none the worse for it. If the flexibility inherent in our colleges' requirements is fairly challenged and tested in this way it could help us to clarify our thinking about the purpose of accreditation and the means of achieving it. What is to be avoided at all costs within the EEC is any kind of legislation concerning postgraduate training requirements which threatens to impose even greater rigidity than we have at present. The concept of a "common trunk" of early postgraduate training is hopeful, if it can be properly developed, as also is the current anxiety within the EEC committees about the inherent impracticability of seeking to insist on the complete training of a specialist.

These issues were discussed at a symposium in Stresa in
1982 assembled at the invitation of the Fondazione Smith Kline. In three intensive days the group reviewed medical demography; student selection; undergraduate, postgraduate, and continuing education; and medical audit. The well prepared opening papers and the whole of the discussion are now available. ${ }^{1}$ One of the particular qualities of the meeting was that it brought together medical practitioners with health economists and administrators in roughly equal numbers, each main topic being introduced by a doctor and either an economist or an administrator. Alan Maynard, who as a health economist worked alongside the chairman Sir John Walton, had characteristically pointed things to say about audit, which he identified as the most important issue in the long run. There is perceptible evidence of progress, at least in terms of receptivity to the concept of audit, and keen interest in initiatives on standard setting and quality control.

At Stresa postgraduate training and medical manpower hung together naturally, as they always must. And they hanged together as they always will-in default of effective collaboration between the interests concerned. With the career structure and the employment of doctors we are all in the tumbril and we look to the health economists, either for last minute absolution or to spell out the terms on which our lives may be spared. If we all try simultaneously to solve the same problems in different ways we can easily nullify each other's efforts. Hence the overriding need for study of medical manpower control mechanisms within the EEC to achieve concerted action. Yet, like many of its constituent nations, the EEC has bodies dealing with manpower that dare not interfere with education, and bodies dealing with training which particularly exclude manpower from their remit. There are partial mechanisms for discussing the problems-but no mechanisms at all for solving them. The Stresa meeting was an important three days, but who will take notice of what was said? Over 18 months have already passed and the published report, sadly, is as fresh as ever.

JAMEs PARKhouse

Director,

Medical Careers Research Group,

Churchill Hospital,

Oxford OX3 7LJ 1 Walton J, Binns TB, eds. Medical education and manpower in the EEC. London: Macmillan Press, in
association with Fondazione Smith Kline, Milan, Italy, 1984.

\section{Metoclopramide and tardive dyskinesia in the elderly}

Metoclopramide may cause several extrapyramidal side effects. Acute dystonic reactions, such as akathisia and spasmodic deviation of the eyes and hands, are more common in children ${ }^{1}$ and tend to occur early in the course of treatment. ${ }^{2}$ In adults they usually coincide with high peak concentrations and disappear rapidly once the drug is stopped. ${ }^{3}$ Early claims that metoclopramide did not cause parkinsonian-like symptoms ${ }^{4}$ have now been refuted. ${ }^{256}$ Parkinsonism induced by metoclopramide is more common in the elderly, has a more rapid onset than Parkinson's disease, and is usually quickly reversed when the drug is stopped.

The suspicion that metoclopramide might be associated with the development of dyskinesia was first raised in 1978,? and further reports have followed. ${ }^{28} \mathrm{~A}$ recent article in the 